\title{
Determinants of Exchange Rate in Ethiopia: A Graphical Approach
}

\author{
Simeneh Almaw \\ Department of Accounting and Finance, Debre Markos University, Debre Markos, Ethiopia
}

\begin{abstract}
The question of exchange rate determination has been just in the core of academic debates. Even though many exchange rate determination models and their amendments have been developed, scholars/writers still cannot agree on which model best describes behavior of exchange rate. Exchange rate is an essential element of the macroeconomic variables that needs to be address in Ethiopia since the Ethiopian birr consistently losing its value and it is necessary to know the factors affecting, in order to analysis the determinate factors, to see which of those possible factors need to be care to control the exchange rate. The objective of this paper was to analysis the relationship among the level of exchange rate in Ethiopia and selected main determinant factors argued in both flow and stock theory of exchange rate determination. The analysis was carried out by detail reviewing the prior researchers work on the area and using correlation and trend analysis for the 18 (2000-2017 G.C) year data obtained from National bank of Ethiopia Quarterly Bulletin. The result shows that nominal exchange rate of Ethiopia relates positively with government spending, broad money supply, inflation level, economic growth, interest rate and negatively with term of trade balance and current account balance. Moreover, it revealed that, government spending; broad money supply and nominal interest rate are the major determinants than inflation, economic growth term of trade balance, and current account balance. Indeed, it is concluded as there is some theoretical and empirical deviations on the result of this study, may be due to the effect of some other missed variables (gov't intervention level, political risk, cultural sentiment.
\end{abstract}

Keywords: Exchange rate, balance of payment theory, Monetary theory, Ethiopia

DOI: $10.7176 / \mathrm{IAGS} / 68-01$

Publication date:July $31^{\text {st }} 2020$

\section{Introduction}

Exchange rate is the price of one country's currency in terms of another country's currency. When transacting internationally, the exchange rate between two countries is a vital factor. After the fail of the Bretton woods agreement, IMF allowed the freedom of each country to choose their-own exchange rate arrangements which ranges from freely floating arrangements at one extreme to fixed arrangements at the other extreme, with the remaining regimes falling in between. Hence after, choose of suitable exchange rate system (no problem on the fixed exchange rate regime), is very important as it will infer different national and international economic policy implication. However, modeling and determining exchange rate behavior is the unsolved issue of the century (Perera \& Jayasuriya, 2016).

The exchange rate affects relation between a country and the other world, in both markets (goods and financial). It affects the volume of both imports and exports (by changing their relative prices), as well as the stock of foreign debt in domestic currency term (Afridi, 1996 cited in Tolcha and Rao 2016). Hence, identifying the sources of exchange rate instability is important to policymakers and researchers to assist them to investigate how to tackle some of the effects of exchange rate changeability (Todani \& Munyama 2005, Mpofu 2013, Aye, Gupta, Moyo \& Pillay 2014; cited in Mpofu 2016). Putting In other words, The level and movements of an exchange rate have been a matter of policy concern for central banks of most countries as unpredictable changes in the exchange rate not only undermine the goal of price stability but also reduce real output, trade, capital flows and investment (IMF, 1984, cited in Abebe (nd))

As stated in Getachew (2015) Ethiopia was developing different exchange rate systems. For instance, in the Empiral and Derge regime, it was a fixed exchange rate with massive appreciation and devaluation between the times in the period. In May 1993, the fortnightly auction exchange rate was introduced. Finally, the auction system was replaced by daily inter-bank exchange rate system in 2001. In this daily inter-bank system, supply and demand are expected to greatly determine the exchange rate; however, national bank of Ethiopia would alter pressure of exchange rate through the reserve requirement. Therefore, it is straight forward to conclude that Ethiopia currently pursues a managed floating exchange rate. According to (Oaikhenan \& Aigheyisi, 2015; Giannellis and Papadopoulos, 2011, cited in Perera \& Jayasuriya, 2016) for a country adopting floating or correspond exchange rate system, exchange rate volatility is an inherited fact in day to day life. They also argued that exchange rate volatility corresponds to large fluctuation around the value or short term fluctuation around the long term average trends of exchange rate. Moreover, they also stated (by citing the work of Martins, 2015) that volatility or change is the movements that are effected in the appreciation or depreciation of the value of one country currency. It resulted on unexpected outcome in any endeavor which undertake internationally and indirectly nationally. Since 
Ethiopia is also pursue managed floating (in smaller manner correspond with floating) exchange rate system, the fluctuation have no exception except the magnitude (amount) of fluctuation (standard deviation of $0.23 \& 5.97$ and range of $1.101 \& 17.68$ for the last 151 days and 18 years respectively). It is more exemplified in (short term and long term respectively) graph 1.

The graph illustrates that monetary policy authority in Ethiopia is faced with the problems of having a stable and realistic exchange rate in short run (with in year) as well as in the last 18 years. Thus, it needs investigating the behavior and determinants of exchange rate in Ethiopia to estimate the exchange rate and decide different economic decisions in some extent certainly because exchange rate instability can have serious adverse consequences on prices, investments and international trade decisions.

Even though, there is no doubt about the importance of knowing the behavior of exchange rate system, modeling and determining exchange rate behavior is the unanswered question of the century (Perera \& Jayasuriya, 2016. some researchers were tried to investigate the determinants of exchange rate in different countries particularly in developed countries which pursued free floating exchange rate. However, those empirical studies have varying results depending on the model adopted and the time they focused: (Aron, Elbadawi \& Kahn (1997); Tensay (2006); Chipili (2012); Parveen, Khan \&Ismail (2012); Ullah, Sial, \& Falak Sher, (2012); Uddin, Quaosar \& Nandi (2013); Kako \& Twarowska (2014); Tadess getachew (2015); Benazic \& Skabic (2016); Mpofu (2016); Perera \& Jayasuriya (2016); Tolcha \& Rao (2016); Works (2016); Umer (2017) and Kilicarslan (2018)) are some of those researchers endeavoring to answer the question what are the factors affecting exchange rate?. Indeed, most of those researchers are from developed country perspective, there is no sufficient literature from developing country perspective; particularly in Ethiopia, up to my best knowledge, no many researchers (in exception of Getachew (2015); Tensay (2006); (Andualem, (1996), Teferi, (2005), Melesse, (2001) and Tolcha \& Rao (2016), determinants of the real exchange rate) trying to identify the determinants of exchange rate. Additionally, the research result dependence on the countries perspective and sampled time period (CERGE-EI, 2007), makes it difficult to know determinants of exchange rate without aggregating many research result with different time horizon. So, it is important to investigate the determinants of exchange rate in Ethiopia. Hence, I tried to present theoretical and some empirical framework about the determinants of exchange rate(focusing on USD dollar in terms of Ethiopian birr, since USD is an international currency and more over it was delimited to nominal exchange rate even if real exchange rate is the ultimate measure of countries competitiveness because since nominal exchange rate persistently determine real exchange rate (Tolcha \& Rao (2016), knowing the behavior of nominal exchange rate enables to estimate the value and direction of real exchange rate ) relying on the following two basic general questions: (1) What are the factors determine the exchange rate? And (2) what is the relationship (trend) between those factors and exchange rate?

As stated in Kilicarslan (2018) even though there is no consent between scholars/writers on the causal factors of exchange rate, many factors have been documented in the literature. Some of those factors are mostly countryspecific; term of Trade balance, economic growth rate, inflation, interest rates, domestic money supply, government expenditure and changes in the balance of payments, are among the commonly mentioned factors. Therefore, under the consideration of different empirical evidence for different time horizon and exchange regime, this study was specifically based on the following hypotheses.

$\checkmark \quad$ The exchange rate and money supply are positively and highly related (positive high correlation or parallel trend expected)

$\checkmark \quad$ Nominal Interest rate (deposit) and exchange rate are negatively and highly correlated (high negative correlation or mirrored trend expected)

$\checkmark \quad$ National gross domestic product (economic growth rate) and government expenditure have positive insufficient relation with exchange rate (parallel trend expected)

$\checkmark$ Inflation rate have positive and large correlation with exchange rate (parallel trend expected)

$\checkmark$ The term of trade balance and balance of payment have negative relation with exchange rate (negative correlation or mirrored trend expected).

\section{Discussion}

In this section of the paper a detailed discussion of theories and previous studies related with exchange rate and its determinants has been presented.

There are two main schools of thought on the exchange rate determinants/determination: 1) balance of payment theory (traditional flow approach): states that exchange rate is dependent on the Balance of payment variables which depends on the relative income and interest differential. This theory advocacy argues that increase in foreign income/national income encourages export/import, in result affects the supply and demand of local currency. Finally, the supply/demand change in local currency affects/determines the exchange rate. This approach uses: elasticity and absorption approach (government expenditure, economic growth and term of trade balance). 2) Monetary (stock) theory: states that exchange rate is function of change in supply/demand of money. It has two versions (monetary approach and asset based approach). Monetary approach uses: purchasing power parity 
condition, Quantity theory of money, Interest rates parity, money demand function (money supply, inflation, interest rate and gov't expenditure) to examine the exchange rate behavior (Saeed, Ullah, Sial, \& Falak Sher, 2012; Hacche 1983 and Branson 1981 cited in Benazic \& Skabic, 2016). In this paper, we use the combination of both approaches, as both are applicable in the Ethiopian context (Tefera, 2004). Chipili (2012) examined the sources of volatility of the exchange rate in Zambian (real and nominal) using the GARCH models and founds that both monetary factors (money supply, inflation, short-term domestic interest rate, and foreign reserves), and real factors (terms of trade, openness, and output) affect exchange rate volatility. The results indicate that real factors have smaller effects on exchange rate than monetary factors. Based on the theory and the above-mentioned literature inspiration, the relationship of the following variable and exchange rate were examined in this paper:

\section{Inflation, GDP growth and Interest rate}

(Perera \& Jayasuriya, 2016) and (Ghalayini 2014, Hossain (2002) cited in Uddin, Quaosar \& Nandi, 2013; Works, 2016) examined the factors that determine nominal exchange rates and revealed that the most important factor affecting nominal exchange rate is inflation and factors driving long-run inflation. My (2016) Was also testing the impact of different macro-economic factors on the foreign exchange rates between USA and four big emerging countries, India, Mexico, Brazil and China for the period of 2005 to 2014 and revealed that GDP is statistically significantly positively related to exchange rate and with Inflation rate, exchange rate has statistically significantly negative relationship with interest rate. Moreover, According to (Mirchandani 2013) exchange rate have direct and positive relationship with inflation and the opposite relationship exists between interest rates exchange rates and he also shows that there is a moderate positive relationship between the GDP growth and Exchange rate, while Abdoh (2016) found insignificant relationship of interest rate and inflation with the exchange rate. Indeed, Parveen, Khan \& Ismail (2012) examined/analyzed some major factors contributing exchange rate volatility and their relative importance in Pakistan and revealed that inflation (positively) and economic growth (negatively) are the main factors affecting exchange rate in Pakistan. The graph below illuminates the relation of exchange rate, inflation and interest rate in Ethiopia. As per the result, nominal exchange rate has no that much relation with inflation and economic growth. The result is as the prior scholar works contrary result, may be due to the effect of exchange rate regime system. In addition to this, the graph also shows that nominal exchange rate has positive and almost strong (parallel) relation with interest rate. It is in contrary with prior works and general theory.

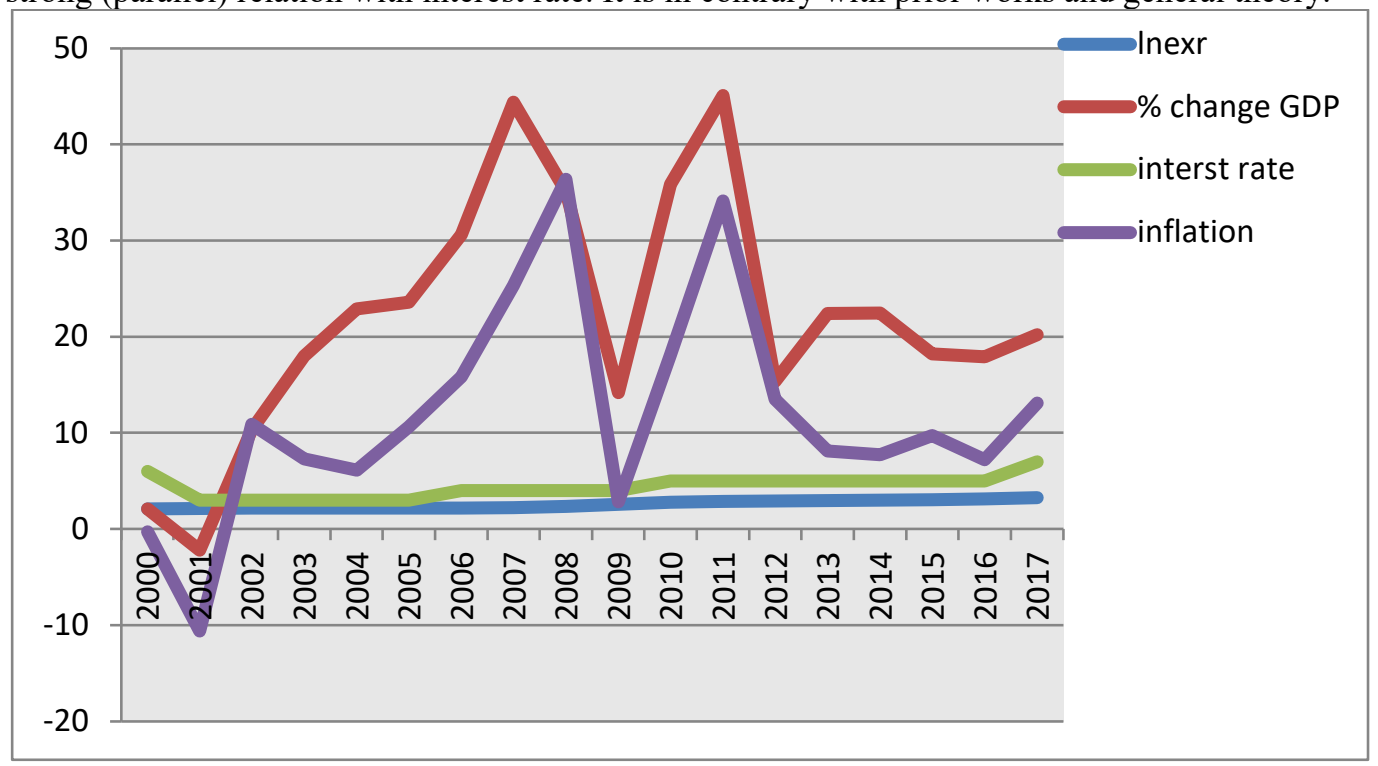

Source: From NBE Data, own compilation, 2019

Correlation of exchange rate with inflation, GDP growth and interest rate is $0.13,0.13$ and 0.73 respectively. It revealed that inflation and GDP growth have no that much relation with exchange rate. Or putting in other word, a unit change in GDP growth and inflation affects 0.13 units. Additionally, the positive sign indicates that increase in GDP growth and inflation deteriorates the value of Ethiopian birr even if it is insignificant.

\section{Money supply and gov't spending}

According to (Works, 2016, Kilicarslan, 2018) Exchange rate variability is high when domestic investment and money supply rise, while the raises in GDP, FDI and government expenditure reduce the variability. Siddiqui et al (1996) and Karfakis (2003) cited in Uddin, Quaosar \& Nandi, 2013) also found that government expenditure negatively affects the exchange rate: means that, the raise in gov't expenditure appreciates the exchange rate and Karfakis (2003) ( cited in Uddin, Quaosar \& Nandi, 2013) found that Money supply is positively related with the 
exchange rate. Means that, Increase in money supply is the source of depreciation in the domestic currency. In light of this, in Ethiopia, I expected to have parallel trend and high positive correlation for the nominal exchange rate of Ethiopian birr in terms of USA dollar and log of government expenditure. The result of this paper is in line with the previous results as illustrated in the graph below. Except the magnitude of the change (elasticity) exchange rate, money supply and government expenditure have parallel trends. Putting in other words, money supply and government expenditure are the major factors of exchange rate in Ethiopia. In supportive to both flow and stock theories, Raise in those two variables result in depreciation of birr.

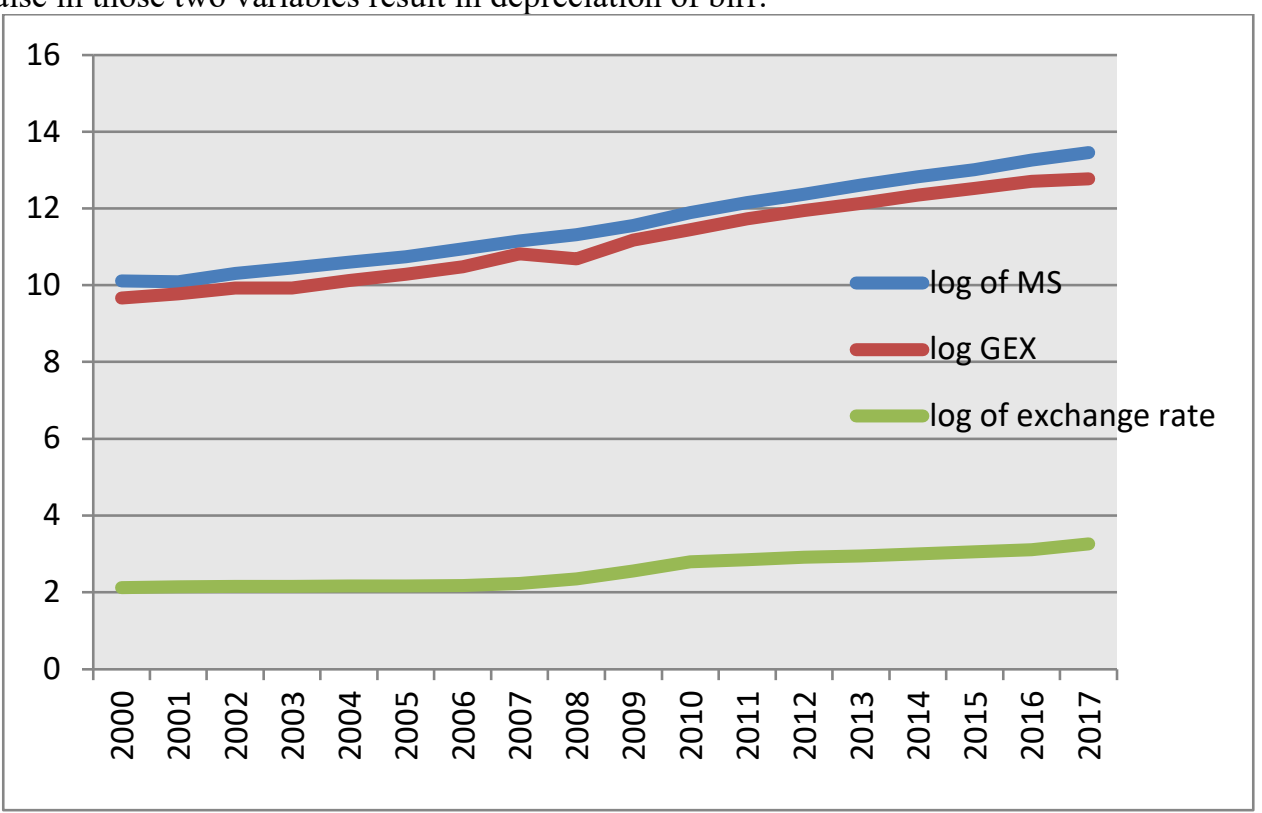

Source: From NBE Data, own compilation, 2019

Moreover, the nominal exchange rate of Ethiopia has correlation of 0.97 with both money supply and government expenditure. It revealed that, money supply and government spending are positively and strongly related with exchange rate (in line with finding of Karfakis (2003); Uddin, Quaosar \& Nandi, (2013) and in contrary with Siddiqui et al (1996)).

\section{Term of trade and current account balance}

Siddiqui et al (1996), cited in Uddin, Quaosar \& Nandi, 2013) finds a positive and insignificant relationship between exchange rate and term of trade. According to My (2016) Trade balance is statistically significantly positively related with exchange rate. Mirchandani (2013) found no relationship between the Current Account and exchange rate. The value of any currency is expected to fall when the current account is in deficit, and more likely to rise when the current account is in surplus.

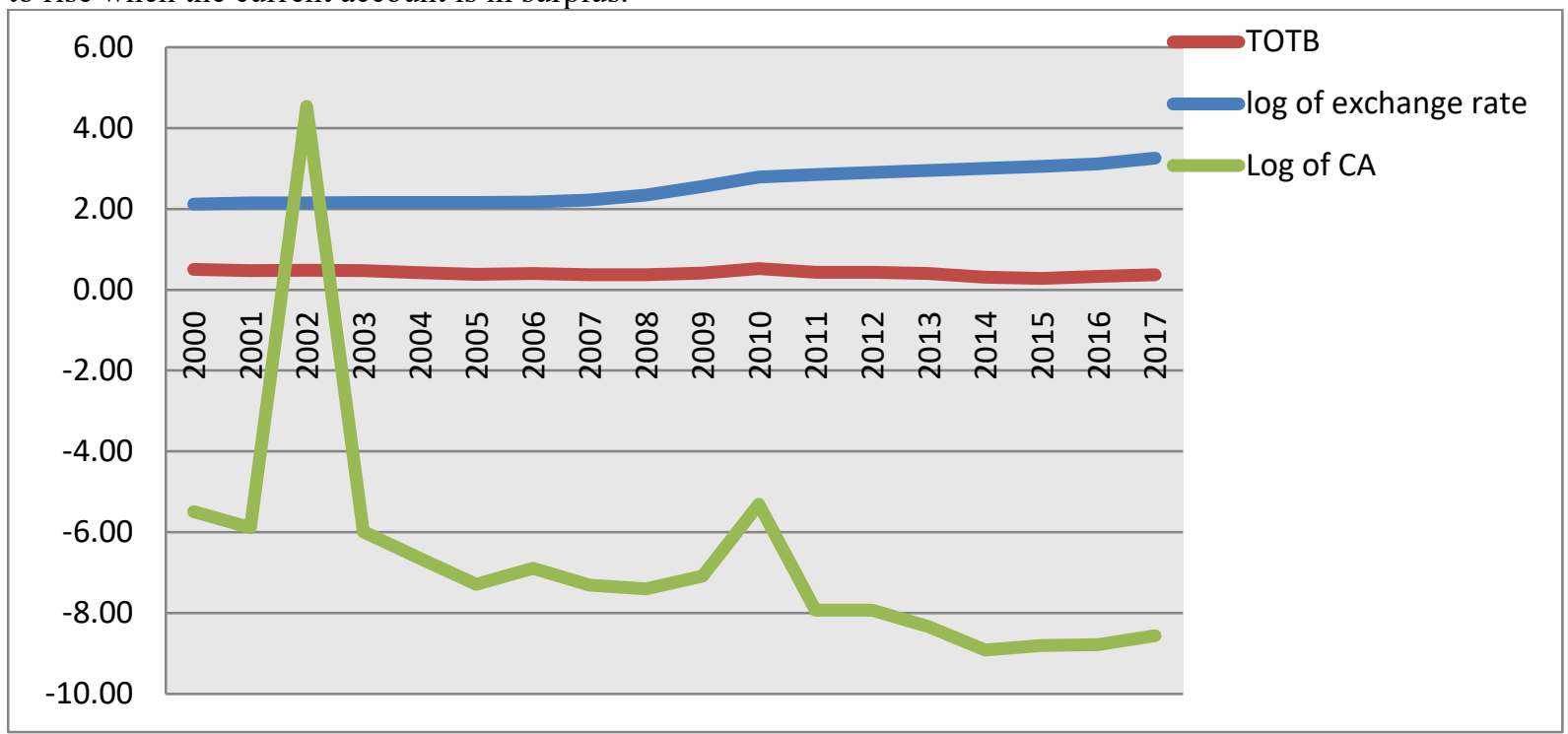

Source: From NBE Data, own compilation, 2019 
The above graph shows that there is reasonable relationship between exchange rate and term of trade balance and current account balance. Even though, the response of exchange rate graph is not immediate with the shock of the graph of current account balance and term of trade it shows inverse relation both with trade balance and current account balance. It implies that; when term of trade improves (export more than import) nominal exchange rate reduced (appreciation of currency). It is evident by opposite trend of the graph. It is same for the case of current account balance. When there is current account balance surplus (upward graph trend), the exchange rate graph down (nominal rate appreciate) and via-vas for deficit. It agrees with the theory of stockman (2016). The correlation matrix also supports the above graph. It is $(-0.48) \&(-0.49)$ for trade balance and current account respectively. Both are less than 0.5 means, trade balance and current account balance are reasonable (expected to be strong for the countries used homogeneous monetary policy, stockman (2016)) determinants (not strong) of exchange rate

\section{Conclusion}

After detail reviewing of the existing empirical evidences (literatures) on exchange rate and its determinants and analyzing the evidence collected from national bank of Ethiopia annual report about the exchange rate and different macro-economic variable, it is concluded that the most important factors relate with exchange rate are broad money supply and government expenditure with almost equal correlational magnitude. It is due to that the increase in government expenditure improves overall consumption and gov't acquisitions of imported goods which intern increase local currency supply and reduce the value (price) of local currency, hence increase the nominal rate of birr to dollar. The same is true for the increase in money supply.

Moreover, the study revealed that inflation and economic growth have weak correlation with nominal exchange rate in Ethiopia. Even if the correlations are positive, it showed that it is positive, meaning that; the increase in inflation or economic growth (income) depreciates the birr to dollar value. Hence, policy makers and decision makers should consider the effect positively (with magnitude) or negatively (with value of birr) with exchange rate. Indeed, in contrary to prior literatures, this paper also showed that nominal exchange rate and interest has strong positive correlation. It implies that, increase in nominal interest rate (deposit) increase the exchange rate of birr to dollar (magnitude) or via-vas. Hence, decision makers' worried for both economic and monetary policy to predict exchange rate

Finally, the relationship between exchange rate and term of trade and current account balance was also investigated. The result showed that, both variables relate negatively with exchange rate almost with equal correlation value. It means that increase in the term of trade balance and current account balance surplus (improve) reduce the nominal exchange rate (appreciate birr). Hence, decision makers should focus on trade policy to stabilize exchange rate.

To sum up, with some exception of empirical and theoretical evidence on the developed world (with freely floating exchange rate), may be because of exchange rate system difference (gov't intervention and missed other variables), both fiscal and monetary policy affects the nominal exchange rate of Ethiopia. Therefore, the concerned party should emphasis all, trade, fiscal and monetary policy to predict and manage exchange rate.

\section{Reference}

Abebe, D. (nd). Exchange Market Pressure and Monetary Policy in Ethiopia, National Bank Of Ethiopia, unpublished

Abdoh,M.Y.M., Yusuf, M.H., Zulkifli, M.A., Bulot,N. \& Ibrahim, J.N. (2016). Macroeconomic Factors That Influence Exchange Rate Fluctuation in ASEAN Countries International Academic Research Journal of Social Science 2(1) Page 89-94

Aron,J. Elbadawi, A. \& Kahn, B. (1997). Determinants of the Real Exchange Rate in South Africa, unpublished

Benazic,m. \& Skabic, k.i. (2016). The determinants of exchange rate in Croatia; eastern journal of European studies volume 7 , issue1.

CERGE-EI, S.J.(2007). Determinants of Exchange-Rate Volatility: The Case of the New EU Members; Finance a úv $\check{r}$ - Czech Journal of Economics and Finance, 57, no. 9-10

Jayasuriya D.P.S.H. \& Perera S.S.N. (2016). Analysis of Factors Affecting USD/LKR Exchange Rate, Symposium on Statistical \& Computational Modeling with Applications-

Kąkol M. \& Twarowska K. (2014). Analysis of factors affecting fluctuations in the exchange rate of polish zloty against euro; Management knowledge and learning international conference.

Khan, I. (2016). Factors effecting exchange rate: a case of Pakistan Online at https://mpra.ub.unimuenchen.de/75209/ MPRA Paper No. 75209, posted 26 November 2016 14:30 UTC

Khan, A. S. R. (2014). Analysis the factors affecting exchange rate variability in Pakistan; Journal of Business and Management (IOSR-JBM) e-ISSN: 2278-487X, p-ISSN: 2319-7668. Volume 16, Issue 6. Ver. II PP 115 121 www.iosrjournals.org

Kilicarslan, Z. (2018). Determinants of exchange rate volatility: empirical evidence for Turkey. Journal of 
Economics, Finance and Accounting (JEFA), Vol.5 (2), p.204-213.

Medina Mohammed Umer. (2017). devaluation and its impact on Ethiopian economy, Hacettepe University Graduate School of Social Sciences, unpublished thesis

Mirchandani, A. (2013). Analysis of Macroeconomic Determinants of Exchange Rate Volatility in India; International Journal of Economics and Financial Issues Vol. 3, No. 1, pp.172-179 ISSN: 2146-4138 www.econjournals.com

Mpofu .R.T. (2016). The Determinants of Exchange Rate Volatility in South Africa University of Cape Town, unpublished

My Q.N. (2016). The Impact of Economic Factors on the Foreign Exchange Rates between USA and Four Big Emerging Countries: China, India, Brazil and Mexico; International Finance and Banking ISSN 2374-2089, Vol. 3, No.

National Bank of Ethiopia2017/18. Quarterly Bulletin Volume 34, No. 4 fourth Quarter fiscal Year Series

Parveen, H. Khan, A.G \& Ismail, M. (2012). Analysis of the factors affecting exchange rate variability in pakistan. Academic research international vol. 2 no.3.

Rao, P.N \& Tolcha, T.D. (2016). "Determinants of real exchange rate in Ethiopia" International Journal of Research, Vol. 4, No. 6 183-210

Saeed, A., Awan, U.R., Sial, H.M., Sher, F. (2012). AN ECONOMETRIC ANALYSIS OF DETERMINANTS OF EXCHANGE RATE IN AKISTAN International Journal of Business and Social Science Vol. 3 No. 6; 184

Stockman, C.A. (1980). A Theory of Exchange Rate Determination; the Journal of Political Economy, Vol. 88, No. 4, pp. 673-698. The University of Chicago Press: http://www.jstor.org/stable/1837308

Tefera L. (2004). Determinants of Parallel Foreign Exchange Market in Ethiopia; National Bank of Ethiopia Economic Research Department NBE Staff Working Paper ERD/SWP/010/2004

Uddin, K.M.K, Quaosar, G.M.A, \&Nandi, D.C. (2013). factors affecting the fluctuation in exchange rate of the Bangladesh: a co-integration approach, international journal of social science, Vol 18, No 1

Works.F.R. (2016). Econometric modeling of exchange rate determinants by market classification: An empirical analysis of Japan and South Korea using the sticky-price monetary theory Capella University MPRA Paper No. 76382, posted 26 January 2017 13:14 UTC (retrieved from https://mpra.ub.uni-muenchen.de/76382/)

\section{Refereed websites}

$\checkmark$ https://radingeconomics.com/ethiopia/indicators

$\checkmark$ www.NBE.com

$\checkmark \quad$ www.IMF.com

Table 1 Abbreviations and definitions

$\% \mathrm{GDP}=$ percentage change in nominal gross domestic product

$\underline{\mathrm{NIR}}=$ nominal deposit interest rate

$\mathrm{IR}=$ inflation rate

TOTB $=$ term of trade balance

$\mathrm{LMS}=\log$ of broad money supply

$\mathrm{LCA}=\log$ of current account balance

$\underline{\text { Loge }}=\log$ of General government expenditure 
Table 2. correlation matrix

\begin{tabular}{|c|c|c|c|c|c|c|c|c|}
\hline & Inexr & GDP & $I R$ & $T B$ & Ims & $L C A$ & $\log e$ & $N I R$ \\
\hline Inexr & 1 & & & & & & & \\
\hline GDP & 0.130095394 & 1 & & & & & & \\
\hline IR & 0.134810432 & 0.865961398 & 1 & & & & & \\
\hline TB & -0.486485117 & -0.20518707 & -0.160080557 & 1 & & & & \\
\hline Ims & 0.976192251 & 0.234033136 & 0.221672345 & -0.6327265 & 1 & & & \\
\hline LCA & -0.497574173 & -0.285361096 & -0.10748005 & 0.586945873 & -0.565283899 & 1 & & \\
\hline loge & 0.977648727 & 0.233732974 & 0.206734756 & -0.623720032 & 0.997183986 & -0.55706036 & 1 & \\
\hline NIR & 0.736231515 & 0.038434672 & 0.130901936 & -0.197617787 & 0.696657072 & -0.420250985 & 0.685853571 & 1 \\
\hline
\end{tabular}

1. Annual data from national bank of Ethiopia quarterly bulletin

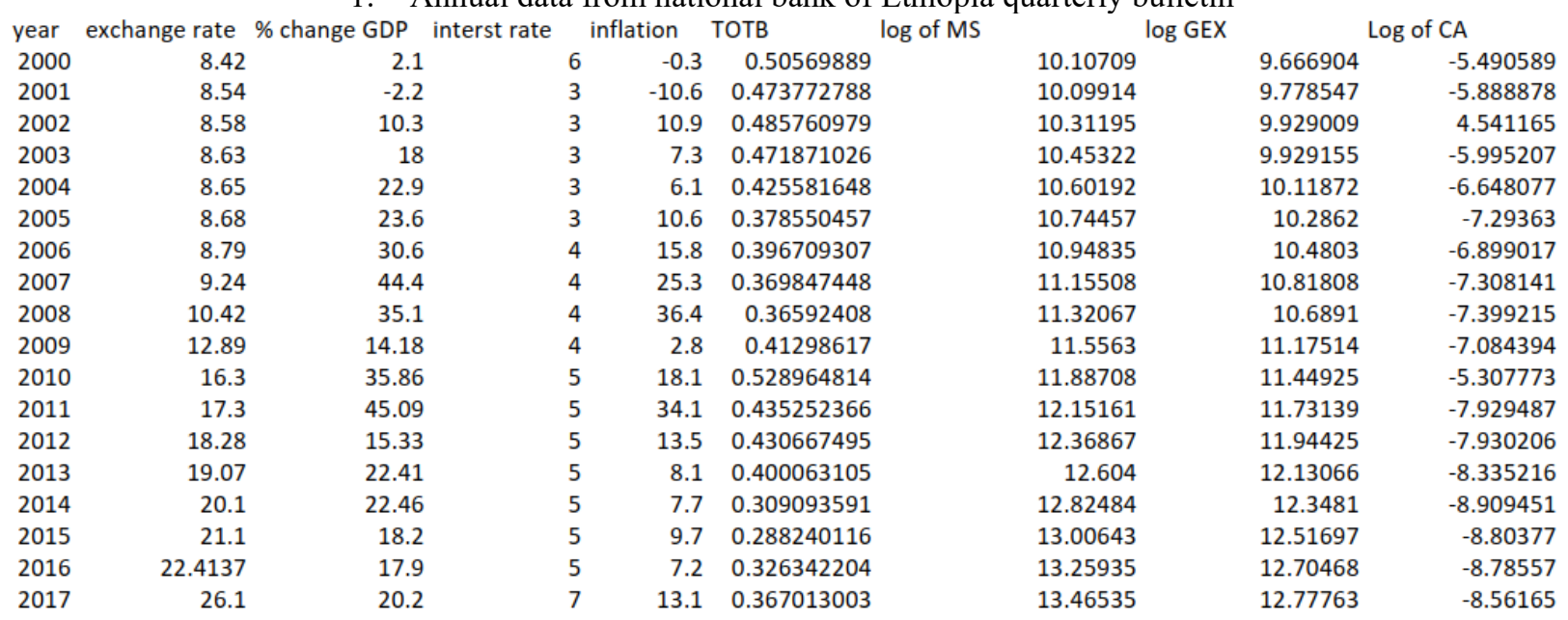

Graph 1 .

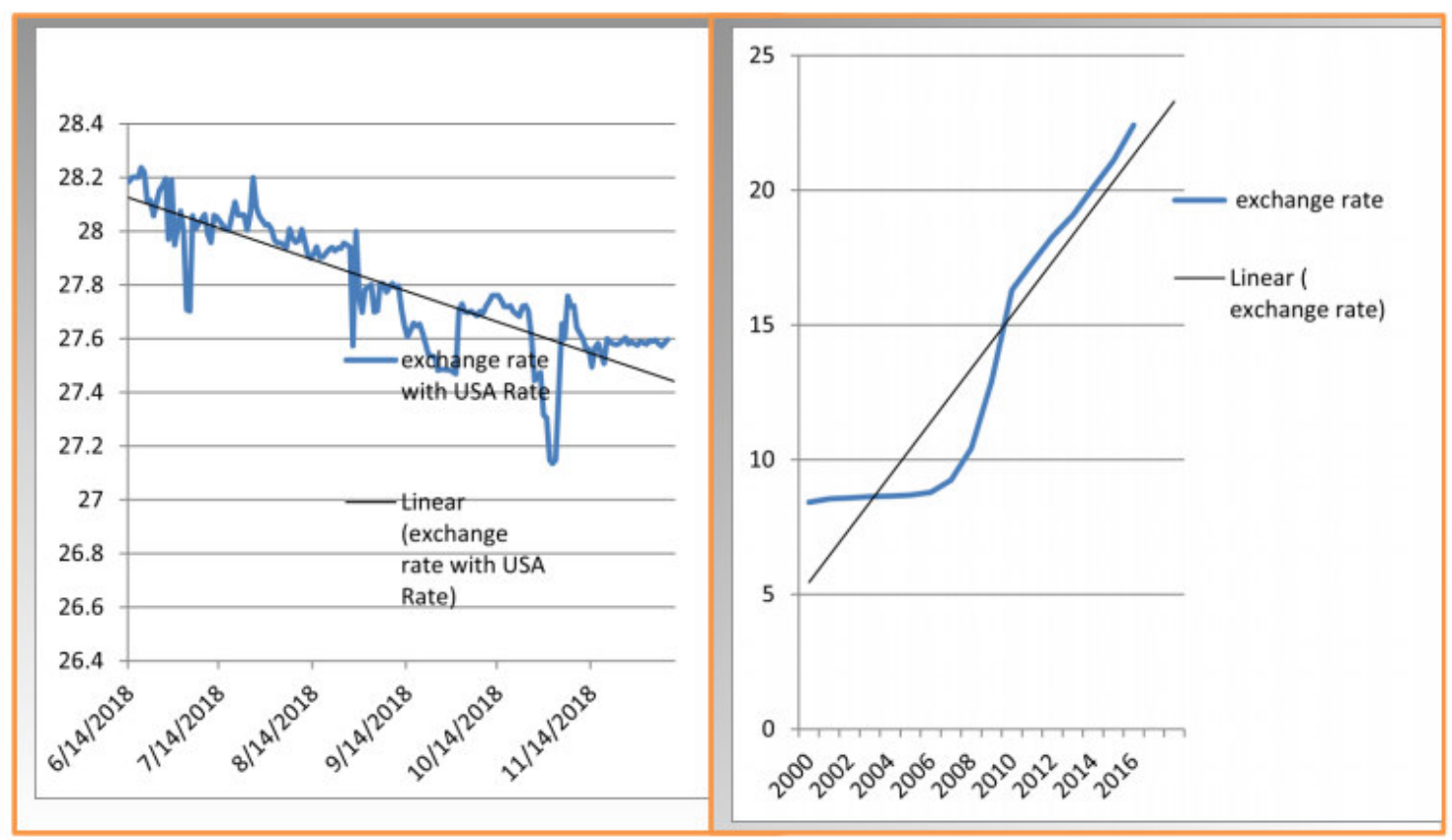

